J. Perinat. Med.

11 (1983) 51

\section{Simultaneous transcutaneous carbon dioxide and transcutaneous oxygen monitoring in neonatal intensive care}

\author{
O. Löfgren, D. Andersson
}

Department of Obstetrics and Gynaecology and Department of Paediatrics, General Hospital, University of Lund, Malmö, Sweden
The first reports on transcutaneous oxygen monitoring (tc $\mathrm{P}_{\mathrm{O}_{2}}$ monitoring), utilizing a membrane electrode was published by EVANS and NAYLOR in 1967 [1] and the technique was presented as a clinical parameter by $\mathrm{HUCH}$ et al. in 1972 [2]. Several studies $[3,6,7,8]$ have reported a statistically highly significant correlation between tc $\mathrm{P}_{\mathrm{O}_{2}}$ and $\mathrm{PaO}_{2}$ and transcutaneous oxygen monitoring is now a routine parameter in many neonatal intensive care units. It was early realized [4] that it should also be possible to measure carbon dioxide transcutaneously (tc $\mathrm{P}_{\mathrm{CO}_{2}}$ ). Such a measurement would be of great help in all intensive care situations with the risk of alvoelar hypoventilation. The following study reports on simultaneous tc $\mathrm{P}_{\mathrm{CO}_{2}}$ and tc $\mathrm{P}_{\mathrm{O}_{2}}$ measurements in a consecutive material of 10 neonatal intensive care patients.

\section{Equipment and procedure}

The equipment used was a Radiometer TCM 222 unit (RADIOMETER, Copenhagen, Denmark). The tc $\mathrm{P}_{\mathrm{O}_{2}}$ electrode was covered by a $12 \mu$ polypropylene membrane using a 'non-water' based electrolyte. The tc $\mathrm{P}_{\mathrm{CO}_{2}}$ electrode was a modified STOW-SEVERINGHAUS electrode without a spacer (Fig. 1). The electrodes were sterilized in Urolicide ${ }^{\circledR}$ according to LÖFGREN [7] before each measurement. Calibration of the oxygen electrode was performed in air before each measurement while zero calibration was performed only after new mounting. The tc $\mathrm{P}_{\mathrm{CO}_{2}}$ electrode was calibrated in carbon dioxide of two different partial pressures ( $5 \%$ and $10 \% \mathrm{CO}_{2}$, respectively). The electrode temperature used both during calibration and measurement was $44^{\circ} \mathrm{C}\left( \pm 0.2^{\circ} \mathrm{C}\right)$. The electrodes were calibrated simultaneously and the time for calibration was about 10 minutes for the oxygen electrode and 20 minutes for the carbon dioxide electrode. The equipment has a built-in circuit which survey the calibration during 6 minutes and accept the electrode only if the in vitro drift is less than $10 \%$ /hour. After calibration the electrodes were applicated in the subclavicular area on both sides of the sternum of the newborn. If the child was treated in CPAP with a face mask, the elec-

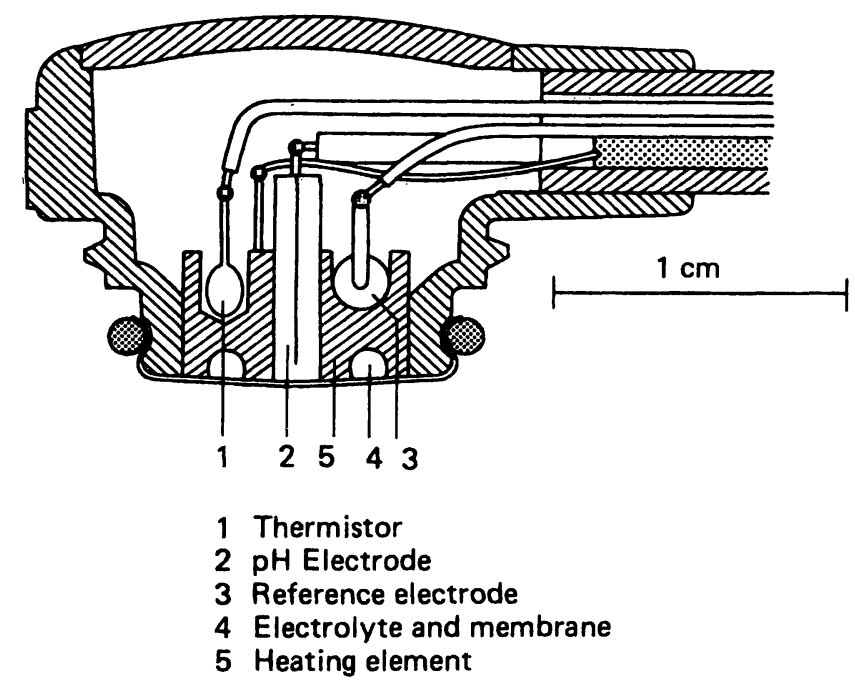

Fig. 1. Electrode for continuous transcutaneous carbon dioxide measurement.

(c) by Walter de Gruyter \& Co. $\cdot$ Berlin $\cdot$ New York 
Tab. I. Patients

\begin{tabular}{rllll}
\hline No. & Sex & $\begin{array}{l}\text { Gestation age } \\
\text { (weeks) }\end{array}$ & $\begin{array}{l}\text { Birth weight } \\
(\mathrm{g})\end{array}$ & Diagnosis , I \\
\hline 1 & $\mathrm{~g}$ & 34 & 3310 & Diabetes matris \\
2 & $\mathrm{~b}$ & 30 & 1260 & Preterm \\
3 & $\mathrm{~b}$ & 29 & 1200 & Preterm, Apnoea rep. \\
4 & $\mathrm{~b}$ & 35 & 1820 & Toxicosis matris \\
5 & $\mathrm{~b}$ & 33 & 2150 & Pneumothorax, IRDS, CPAP \\
6 & $\mathrm{~g}$ & 28 & 970 & Preterm, Bronchopneumonia, IRDS, CPAP \\
7 & $\mathrm{~b}$ & 31 & 1500 & Preterm, Pneumothorax, IRDS, CPAP \\
8 & $\mathrm{~b}$ & 30 & 1920 & Preterm, Icterus neonat. \\
9 & $\mathrm{~g}$ & 36 & 2260 & IRDS, Hyperbil. \\
10 & $\mathrm{~g}$ & 30 & 880 & Preterm \\
\hline
\end{tabular}

$\mathrm{g}=$ girl

$\mathrm{b}=$ boy

trode application site was a little more caudal, in one patient even on the abdominal wall. The oxygen concentration of the respired air was measured with an oxygen analyzer (Ivac 1225, AGA, Sweden). Arterial blood samples were drawn from an umbilical artery catheter with the tip of the catheter placed in the level of L2-L3 (X-ray). $\mathrm{PaO}_{2}$ and $\mathrm{PaCO}_{2}$ was analyzed with Radiometer $\mathrm{ABL} 1$ equipment (RADIOMETER, Copenhagen, Denmark). $\mathrm{FiO}_{2}$ was changed only for clinical reasons. Attempts were made to get at least three arterial samples during each electrode application and each measurement session with an electrode temperature of $44^{\circ} \mathrm{C}$. After measurement the electrode drift was calculated by recalibration.

\section{Patients}

Recordings were performed in 10 consecutive patients during totally 23 sessions. The patients had been referred to the intensive care unit because of immaturity or respiratory problems (Tab. I). Three out of four patients with IRDS were treated in CPAP. In two of these children a pneumothorax was diagnosed. One of the patients was slightly hypothermic at the beginning of the recording (No. 3), the other patients being normothermic.

\section{Results}

The mean registration time was 8 hours (range 60-1860 min) (Tab. II). After application of the electrode and a stabilization period of about 10 minutes the recording started. Both recordings showed oscillatory patterns, the tc $\mathrm{P}_{\mathrm{CO}_{2}}$ oscillations being less argumented than the oscillation of the tc $\dot{\mathrm{P}}_{\mathrm{O}_{2}}$ recording (Fig. 2; Tab. II). The oscillatory pattern was correlated to the neonatal breathing pattern and the activity of the child.

There was a statistically highly significant correlation between arterial and transcutaneously obtained values (tc $\mathrm{P}_{\mathrm{CO}_{2}}: \mathrm{r}=0.85, \mathrm{n}=53$; tc $\mathrm{P}_{\mathrm{O}_{2}}$ : $\mathrm{r}=0.95, \mathrm{n}=50$ ) (Figs. 3 and 4). The mean tc $\mathrm{P}_{\mathrm{O}_{2}}$ and tc $\mathrm{P}_{\mathrm{CO}_{2}}$ at a steady state with normal blood gases was 10.3 and $7.8 \mathrm{kPa}$, respectively, calculated from the minute-to-minute values 5 minutes before and 5 minutes after the blood samples were obtained. A comparison of simultaneously

Tab. II. tc $\mathrm{PO}_{2}$ and tc $\mathrm{PCO}_{2}$ during 23 measurement sessions in 10 patients at steady state

\begin{tabular}{|c|c|c|c|c|c|}
\hline & $\begin{array}{l}\text { Mean level } \\
(\mathrm{kPa})\end{array}$ & $\begin{array}{l}\text { Oscillation amplitude } \\
(\mathrm{kPa})\end{array}$ & $\begin{array}{l}\text { Max decrease/increase } \\
\text { during apnoe } \\
(\mathrm{kPa})\end{array}$ & $\begin{array}{l}\text { Diff } \\
37 / 44^{\circ} \mathrm{C} \\
(\mathrm{kPa})\end{array}$ & $\begin{array}{l}\text { Reg time } \\
\text { (min) }\end{array}$ \\
\hline $\begin{array}{l}\text { tc } \mathrm{PO}_{2} \\
\text { tc } \mathrm{PCO}_{2}\end{array}$ & $\begin{array}{r}10.3 \\
7.8\end{array}$ & $\begin{array}{l}4.6 \\
1.5\end{array}$ & $\begin{array}{l}9.4 \\
2.7\end{array}$ & $\begin{array}{l}4.6 \\
1.9\end{array}$ & $\begin{array}{l}480 \\
\text { range } 60-1860\end{array}$ \\
\hline
\end{tabular}




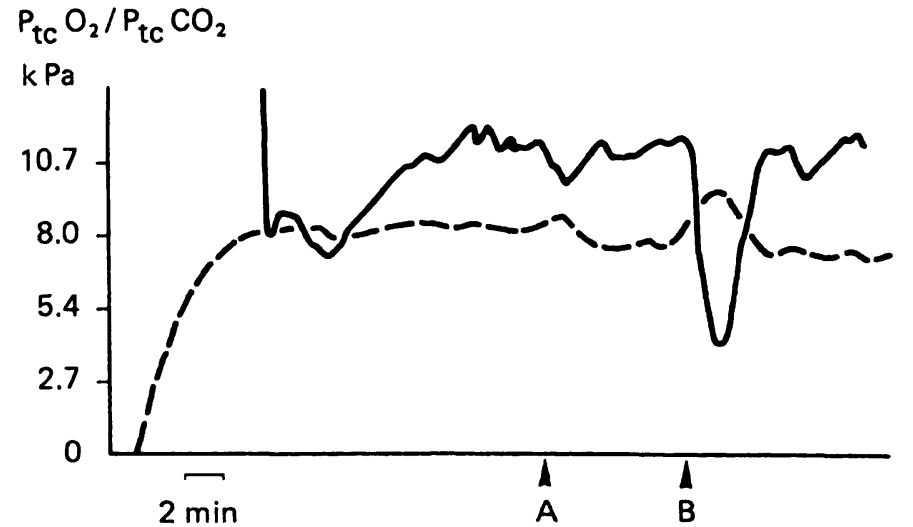

Fig. 2. Recording showing tc $\mathrm{PO}_{2}(-)$ and tc $\mathrm{PCO}_{2}$ $(---)$. Note the stabilization time, the difference in oscillation amplitude and the change in partial pressure at apnoe (A and B).

obtained values for tc $\mathrm{P}_{\mathrm{CO}_{2}}$ and tc $\mathrm{P}_{\mathrm{O}_{2}}$ showed that the oscillation amplitude was $1.5 \mathrm{kPa}$ for tc $\mathrm{P}_{\mathrm{CO}_{2}}$ compared to $4.6 \mathrm{kPa}$ for tc $\mathrm{P}_{\mathrm{O}_{2}}$. During apnoea tc $\mathrm{P}_{\mathrm{CO}_{2}}$ increased in mean $2.7 \mathrm{kPa}$ simultaneous to a decrease of tc $\mathrm{P}_{\mathrm{O}_{2}}$ of $9.4 \mathrm{kPa}$ obtained from a total of 35 apnoic incidences in 5 children. When the electrode temperature was decreased from $44{ }^{\circ} \mathrm{C}$ to $37^{\circ} \mathrm{C}$, both tc $\mathrm{P}_{\mathrm{CO}_{2}}$ and tc $\mathrm{P}_{\mathrm{O}_{2}}$ decreased $(1.9 \mathrm{kPa}$ and $4.6 \mathrm{kPa}$, respectively). Also at the lower electrode temperature changes in central blood gases were reflected by the transcutaneous measurement. At an electrode temperature of $37^{\circ} \mathrm{C}$, the tc $\mathrm{P}_{\mathrm{O}_{2}}$ recording showed a 'silent pattern' [9] while the tc $\mathrm{P}_{\mathrm{CO}_{2}}$ recording was less influenced. When the electrode temperature was again increased, both tc $\mathrm{P}_{\mathrm{O}_{2}}$ and tc $\mathrm{P}_{\mathrm{CO}_{2}}$ resumed their origninal levels (Tab. II).

The neonatal breathing pattern was surveilled by use of apnoea matresses in all immature infants in a clinically stable condition. In four severe immature children who later developed apnoea repetens, an increased frequency of apnoic periods was diagnosed about 45 minutes before alarm from the apnoea matress. The apnoic periods, initially resulted in short time changes of the blood gas levels (Fig. 2), but later on became more frequent with more argumented changes with alarm from the apnoea matress. In one of these patients (No. 6), the increase frequency of apnoea was diagnosed when the electrode had the 'resting temperature' of $37^{\circ} \mathrm{C}$.

The electrodes were usually applicated in the subclavicular area. There was no obvious difference in the recording if the electrode was applicated a little more caudal, as described for children in CPAP. As a result of the electrode temperature of

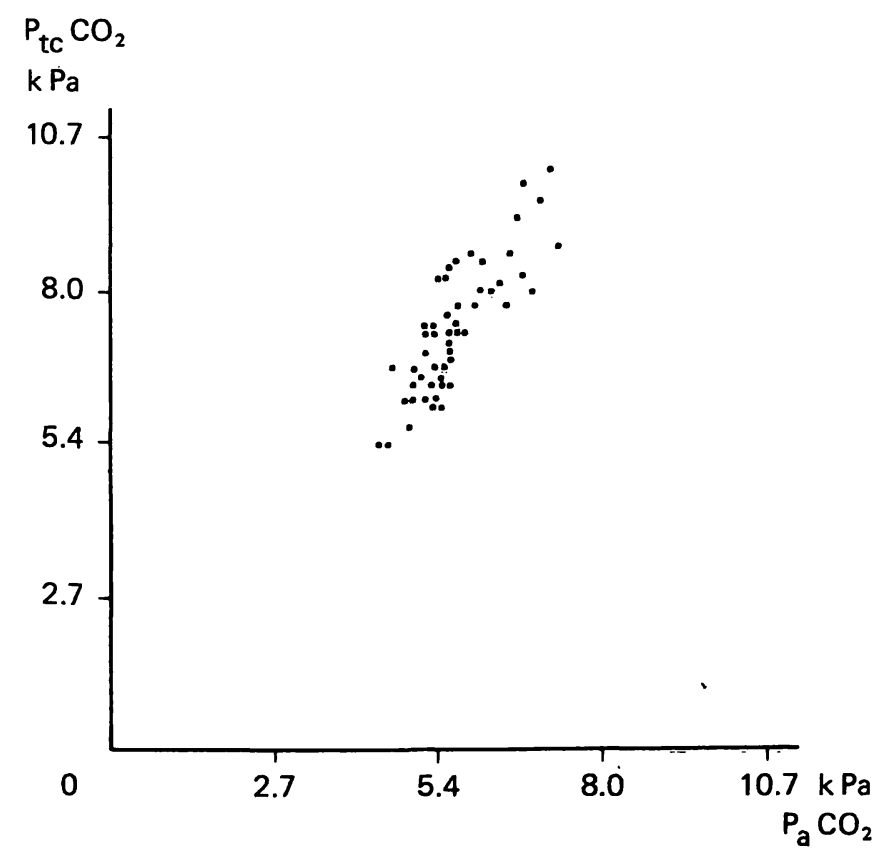

Fig. 3. Correlation between tc $\mathrm{PCO}_{2}$ and $\mathrm{PaCO}_{2}$.

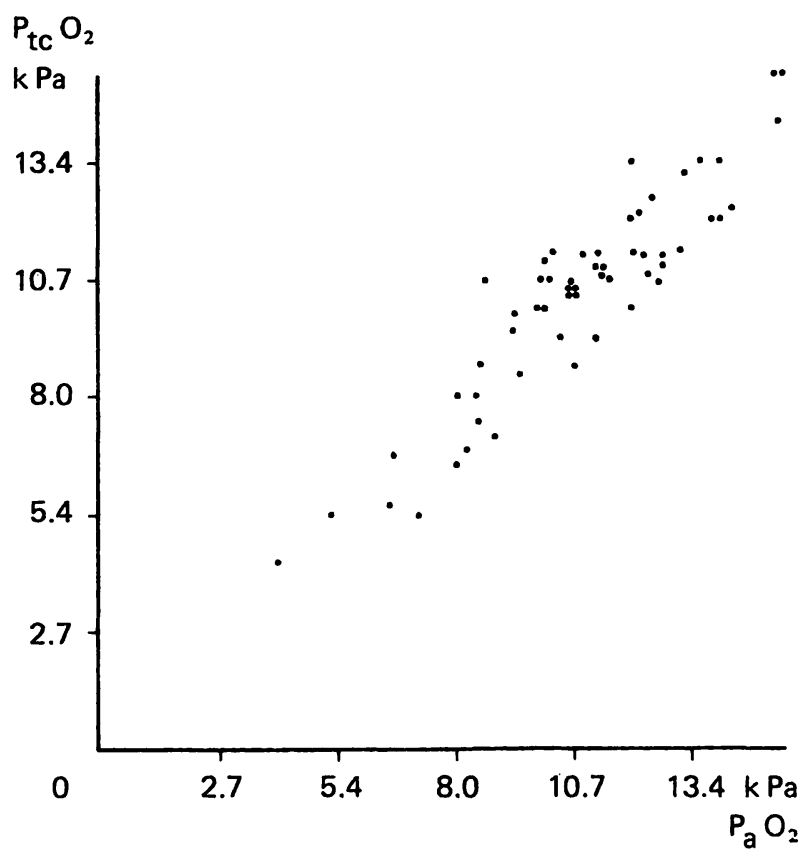

Fig. 4. Correlation between tc $\mathrm{PO}_{2}$ and $\mathrm{PaO}_{2}$. 
$44{ }^{\circ} \mathrm{C}$, a red mark was produced at the electrode application site. This red mark disappeared within the next 24 hours in most patients. One patient, measured continously for 3.5 hours, got blisters from both electrodes (Patient No.9), while another patient, where the electrodes were left in situ for 31 hours with intermittent resting periods (patient No. 2), did not show any burns. The electrode drift was low and always less than $1.5 \mathrm{kPa}$ for both electrodes.

\section{Discussion}

Calibration of the electrode was surveyed by the central instrument and the electrode should have been rejected if the in vitro drift had been $>10 \% /$ hour ( $>6 \%$ /hour for the commercial equipment). There was no strict time interval between remounting of the electrodes but during periods of continuous use, new mounting was necessary about 4 times/week. The $\mathrm{CO}_{2}$ electrode was calibrated at two levels demanding a calibration time of 15-20 minutes. Using only one-point calibration, the time is reduced to 10 minutes but this may result in a non-linearity of the electrode at high $\mathrm{PaCO}_{2}$ levels.

The electrode drift obtained from the recalibration values was very low. As has been shown by LÖFGREN $[7,10]$ the recalibration values does not seem to express the true in vivo drift. The length of the stabilization period and the oscillatory pattern seems to be better indices of the reliability of the recording.

There was a statistically highly significant correlation between arterial and transcutaneously obtained values. tc $\mathrm{P}_{\mathrm{CO}_{2}}$ was consistently a little higher than $\mathrm{PaCO}_{2}\left(\mathrm{tc} \mathrm{P}_{\mathrm{CO}_{2}}=1.3 \times \mathrm{PaCO}_{2}\right)$. It should be emphasized that the correlation between arterial and transcutaneous values was even higher within patients than for the total material with an almost linear regression at every measurement occasion. This is consistent with the reports that the relationship between transcutaneous and arterial values may vary among patient while this relationship is very constant within the same patient at the same measurement occasion [7, 8].
There was no obvious difference, neither in the recorded levels or in sensitivity of the electrode expressed as oscillatory pattern, if the application area was a little more caudal than usual. Thus, also if the electrodes were applicated on the abdomen the recording reacted very sensitively to changes in the neonatal breathing pattern. This is consistent with previous reports for the tc $\mathrm{P}_{\mathrm{O}_{2}}$ electrode [5].

The respiratory pattern was always surveilled by a nurse and the child was always lying on an apnoic matress. In all patients, who later developed apnoea repetens, it was possible to, retrospectively, diagnose the increased frequency of apnoic periods 45 minutes before the alarm of the apnoea matress (apnoea during $15 \mathrm{sec}$ ). The changes were initially short timed and discrete but successively became more argumented and frequent, emphasizing the sensitivity of the method. In one child, such apnoic periods were diagnosed with an electrode temperature of $37^{\circ} \mathrm{C}$. At this lower electrode temperature, oscillation pattern of the tc $\mathrm{P}_{\mathrm{O}_{2}}$ recording was changed to a 'silent pattern' while the oscillation pattern of the tc $\mathrm{P}_{\mathrm{CO}_{2}}$ recording was less influenced. This implies that the tc $\mathrm{P}_{\mathrm{CO}_{2}}$ recording is less sensitive to changes in 'arterilization'.

In one of the patients a second degree burn was produced by the electrode temperature of $44^{\circ} \mathrm{C}$. The patient was neither the most immature nor had the child a decreased skin circulation and it seems as if burns from the electrode may appear at random. This is consistant with experience from tc $\mathrm{P}_{\mathrm{O}_{2}}$ monitoring [8]. Thus, tc $\mathrm{P}_{\mathrm{CO}_{2}}$ measurement with an electrode temperature of $37^{\circ} \mathrm{C}$ might be used in severely immature children with a thin epidermis where the risk of iatogenic burns with the higher electrode temperature is obvious. If measurements are performed at $44^{\circ} \mathrm{C}$, shorttime measurements are recommended with the electrode ,stored' at a lower electrode temperature and in situ on the skin, between the recordings.

The technique for continous transcutaneous carbon dioxide monitoring is ready for clinical use and is a valuable additional tool in all neonatal intensive care patients with the risk of alveolar hypoventilation. 


\section{Summary}

Continous transcutaneous carbon dioxide partial pressure (tc $\mathrm{PCO}_{2}$ ) and continous transcutaneous oxygen partial pressure $\left(\mathrm{tc} \mathrm{PO}_{2}\right)$ was monitored simultaneously in 10 consecutive neonatal intensive care patients treated for respiratory problems or immaturity. During measurement the electrode temperature was $44^{\circ} \mathrm{C}$ while during the resting periods - with the electrodes left in situ - the electrode temperature was $37^{\circ} \mathrm{C}$. Measurements were performed for periods up to 31 hours. It was possible to discover changes in central blood gas partial pressures also at the lower electrode temperature. This was especially true for the tc $\mathrm{PCO}_{2}$ recording which was less influenced by the decrease in electrode temperature than the tc $\mathrm{PO}_{2}$ recording. In six patients an increased frequency of apnoea was diagnosed by the transcutaneous blood gas monitoring equipment previous to other clinical signs. A statistically highly significant correlation was found between transcutaneous and arterial blood gas values, the arterial samples obtained from umbilical artery catheters. tc $\mathrm{PCO}_{2}$ and tc $\mathrm{PO}_{2}$ very sensitively reacts to changes in the breathing pattern and to changes in activity of the neonate emphasizing the drawbacks of previous blood gas monitoring techniques. The technique for continous transcutaneous carbon dioxide monitoring is ready for clinical use and is a valuable additional tool in all neonatal intensive care patients with the risk of alveolar hypoventilation.

Keywords: alveolar, hypoventilation, apnoea, neonatal intensive care, transcutaneous carbon dioxide monitoring, transcutaneous oxygen monitoring.

\section{Zusammenfassung}

Simultanmessungen des transcutanen $\mathrm{CO}_{2}$ und $\mathrm{O}_{2}$ auf einer neonatalen Intensivstation

Bei 10 neonatalen Intensivpflegepatienten, die wegen respiratorischer Insuffizienz oder Unreife behandelt wurden, haben wir simultan den transcutanen $\mathrm{CO}_{2}$-Partialdruck (tc $\mathrm{PCO}_{2}$ ) sowie den transcutanen $\mathrm{O}_{2}$-Partialdruck (tc $\mathrm{PO}_{2}$ ) kontinuierlich aufgezeichnet. Während der Messungen betrug die Temperatur an der Elektrode $44^{\circ} \mathrm{C}$, in den Meßpausen dagegen $37^{\circ} \mathrm{C}$, wobei die Elektrode in situ belassen wurde. Die Meßperioden betrugen bis zu 31 Stunden. Wir konnten auch bei der niedrigeren Elektrodentemperatur Änderungen der Partialdrucke im Blut aufdecken. Das galt besonders für die tc $\mathrm{PCO}_{2}$-Messung, die weniger durch einen Temperaturabfall an der Elektrode beeinflußt wurde als die tc $\mathrm{PO}_{2}$-Messung. Bei 6
Patienten wurde mittels der transcutanen Blutgasmessung eine Zunahme an Apnoe-Phasen vor allen anderen klinischen Zeichen registriert. Wir fanden eine statistisch hochsignifikante Korrelation zwischen transcutan gemessenen und arteriell bestimmten Blutgaswerten, wobei die arteriellen Blutproben über einen Nabelarterienkatheter gewonnen wurden. Der tc $\mathrm{PCO}_{2}$ und tc $\mathrm{PO}_{2}$ reagieren sehr empfindlich auf Veränderungen des Atemmusters und der Aktivität des Neugeborenen, was sehr deutlich die Nachteile der früheren Technik zur Blutgasbestimmung aufzeigt. Die Methode der transcutanen $\mathrm{CO}_{2}$-Messung kann im klinischen Alltag Anwendung finden; sie ist ein wertvolles zusätzliches Hilfsmittel auf neonatalen Intensivstationen bei Patienten mit dem Risiko einer alveolären Hypoventilation.

Schlïsselwörter: Alveoläre Hypoventilation, Apnoen, neonatale Intensivstation, transcutane $\mathrm{CO}_{2}-\mathrm{Messung}$, transcutane $\mathrm{O}_{2}$-Messung.

\section{Résumé}

Surveillance simultanée du $\mathrm{CO}_{2}$ et de l'oxygène transcutanes, en soins intensifs néo-nataux

La pression partielle transcutanée continue de dioxyde de carbone (tc $\mathrm{PCO}_{2}$ ) et la pression partielle transcutanée continue d'oxygène (tc $\mathrm{PO}_{2}$ ) ont été surveillées simultanément chez 10 patients consécutifs en unité de soins intensifs néonataux traités pour des problèmes respiratoires ou pour immaturité. Pendant les mesures la température de l'électrode était de $44^{\circ} \mathrm{C}$ tandis qu'au repos - l'électrode laissée in situ - la température était de $37^{\circ} \mathrm{C}$. Les mesures ont été réalisées pendant des périodes allant jusqu'à 31 heures. Il a été possible de découvrir des modifications des pressions partielles gazeuses sanguines centrales également à la température d'électrode la plus.basse. Ceci est particulièrement vrai pour l'enregistrement de la tc $\mathrm{PCO}_{2}$ qui est moins influencé par la diminution de la température de l'électrode que l'enregistrement de la tc $\mathrm{Po}_{2}$. Chez 6 patients une fréquence augmentée d'apnées a été diagnostiquée grâce à l'équipement d'enregistrement transcutané des gaz sanguins avant tout autre signe clinique. Une corrélation hautement significative sur le plan statistique a été trouvée entre les valeurs transcutanées et celles du sang artériel; les échantillons de sang artériel ayant été obtenus par cathétérisme artériel ombilical. $\mathrm{La}$ tc $\mathrm{PCO}_{2}$ et la tc $\mathrm{PO}_{2}$ réagissent précisément aux changements de fréquence respiratoire et à l'activité du nouveau-né ce qui accentue les inconvénients des techniques antérieures de monitorage des gaz du sang. La technique de surveillance en continu du dioxyde de carbone transcutanée est prête pour l'utilisation clinique et représente un outil additionel valable chez tous les nouveaux-nés en soins intensifs, à risque d'hypoventilation alvéolaire.

Mots-clés: Apnée, hypoventilation alvéolaire, soins intensifs néonataux, surveillance de l'oxyène transcutané, surveillance du dioxyde de carbone transcutané. 


\section{Bibliography}

[1] EVANS, N. T. S., P. F. D. NAYLOR: The systemic oxygen supply to the surface of human skin. Respiratory Physiology 3 (1967) 21

[2] HUCH, R., D. W. LÜBBERS, A. HUCH: Quantitative continuous measurement of partial oxygen pressure on the skin of adults and newborn babies. Pflügers Arch. Ges. Physiol. 337 (1972) 185

[3] HUCH, A., R. HUCH: Transcutaneous non-invasive monitoring of $\mathrm{PO}_{2}$. Hospital Practice 11 (1976) 43

[4] HUCH, R., D. W. LÜBBERS, A. HUCH: The transcutaneous measurement of oxygen and carbon dioxide tensions for the determination of arterial blood-gas values with control of local perfusion and peripheral perfusion pressure. Theoretical analysis and practical application. In: PAYNE, J.P., D.W. HILL (eds.): Oxygen Measurement in Biology and Medicine, Butterworth, London 1975

[5] JACOBSSON, L., O. LÖFGREN: Transcutaneous monitoring of $\mathrm{PO}_{2}$ in different skin areas in the neonate and in the scalp of the fetus during labour. - Methodological and physiological observations. Acta Obstet. Gyneac. Scand. Suppl. (1977) 66

[6] JAMES, L. S.: Development and clinical evaluation of blood gas sensors for continuous monitoring (adult and neonate). U.S. Department of Commerce National Technical Information Service (1976) 1
[7] LÖFGREN, O.: On transcutaneous $\mathrm{PO}_{2}$ measurements in humans. Some' methodological, physiological and clinical studies. Thesis. Department of Obstetrics and Gynecology, University of Lund, General Hospital, Malmö, Sweden.

[8] LÖFGREN, O., P. HENRIKSSON, L. JACOBSON, Ö. JOHANSSON: Transcutaneous $\mathrm{PO}_{2}$ monitoring in neonatal intensive care. Acta Paediat. Scand. 67 (1978) 693

[9] LÖFGREN, O., L. JACOBSON: Some characteristics of transcutaneously monitored oxygen partial pressure in normal newborns. Acta Paediat. Scand. 68 (1979) 789

[10] LÖFGREN, O.: The effect on the responsivity of the tc $\mathrm{PO}_{2}$ electrode by an increased pressure on the electrode membrane. Scand. J. Clin. Lab. Invest. 41 (1981) 171

Received June 22, 1982. Revised August 6, 1982. Accepted October 21, 1982.

Olof Löfgren, M. D.

University of Lund

Dept. Obstet. \& Gynecology

Allmänna Sjukhuset

Kvinnolkiniken I Malmö

S-214 01 Malmö/Sweden 